\title{
Frequency of the most common CYP3A5 polymorphisms in the healthy population of the Republic of Macedonia
}

\author{
Krume Jakovski ${ }^{1}$, Aleksandra Kapedanovska Nestorovska ${ }^{2}$, Nikola Labacevski ${ }^{1}$, \\ Aleksandar J. Dimovski* \\ ${ }^{1}$ Department of Preclinical and Clinical Pharmacology and Toxicology, Faculty of Medicine, \\ University "Ss Cyril and Methodius", Skopje, Republic of Macedonia \\ ${ }^{2}$ Center for Bimolecular and Pharmaceutical Analysis, Faculty of Pharmacy, \\ University "Ss Cyril and Methodius", Skopje, Republic of Macedonia
}

Received: June 2012; Accepted: August 2012

\begin{abstract}
The genetic polymorphism affecting the CYP3A5 enzyme is responsible for inter-individual and interethnic variability in the metabolism of CYP3A 5 substrates. The aim of this study was to analyze the distribution of the most common CYP3A $5 * 3$ allelic variants in the healthy population of R. Macedonia and to investigate if the allelic frequency falls within the assumed range for European Caucasians. The total of 174 healthy volunteers from the general population were included. The genotyping of the CYP3A5*3 variant alleles, *3A (rs 15524 ) and *3E (rs28365095), was performed with Real-Time PCR based on the allelic discrimination method using a TaqMan SNP genotyping assay according to the manufacturer's instructions. The CYP3A5*3 allele is abundantly present displaying an allelic frequency of 0.922 . We estimate that 0.82 of the Macedonian population are homozygotes for the variant and do not have a CYP3A5 enzymatic activity.

Our study demonstrated a high prevalence of CYP3A $5 * 3$ allele in the Macedonian population. The distribution of CYP3A5 alleles was similar to that found in other European Caucasians. As the goals of personalized medicine are beginning to be realized, this provides basic information on the CYP3A5 allele frequency for the future pharmacogenetic research in R. Macedonia.
\end{abstract}

Key words: allelic variants, CYP3A5, population frequency, R. Macedonia

\section{Introduction}

Isoforms of the cytochrome P450 (CYP) 3A subfamily are the most abundantly expressed CYP enzymes in the human liver. They participate in the metabolism of endogenous compounds, bile acids and steroids (such as aldosterone, testosterone, and estrogens), but also in the biotransformation of approximately $50 \%$ of the currently marketed drugs (steroids, antidepressants, immunosuppressive agents and antibiotics) (Paine et al., 2006).

Substantial inter-individual differences in the CYP3A enzyme expression contribute to the divergence in oral bioavailability and systemic clearance of CYP3A substrates.

\footnotetext{
*adimovski@ff.ukim.edu.mk

tel/fax:++38923126054
}

Estimates of the relative involvement of a genetic variation relevant to the CYP3A function indicate that 70 to $90 \%$ of inter-individual variability is attributable to genetic factors (He et al., 2006).

The CYP3A gene family consists of four genes $(C Y-$ $P 3 A 4, C Y P 3 A 5, C Y P 3 A 7$, and CYP3A43) clustered in a region of about $220 \mathrm{~kb}$ in chromosome 7q21 (Kuehl et al., 2001; Garsa et al., 2005). In human adults, CYP3A4 and CYP3A5 are the predominant functional CYP3A isoforms. Although single nucleotide polymorphisms (SNPs) have been found in the coding region of CYP3A4, they are rare and appear to have limited impact on CYP3A4 and the total CYP3A activity. CYP3A5 is the primary extrahepatic CYP3A isoform and typically displays a decreased catalytic activity compared to CYP3A4. So far, 13 genetic polymorphisms have been described for CYP3A5 (Huang et al., 2004). The genetic basis for polymorphically expressed CYP3A5 has been associated with SNP in intron 3 of the 
CYP3A5 gene (CYP3A5*3C; g.6986A>G) (King et al., 2003). CYP3A5*3C mutant allele is the major defective allele, leading to alternative splicing and protein truncation, which in turn results in the absence of the enzyme activity. This variant is the only one reported in all ethnic groups and is therefore considered the most ancient allele. SNPs in the $3{ }^{\prime} \mathrm{UTR}$ (CYP3A5*3A, g. 31611C>T) and in the intron $10(\mathrm{CYP} 3 \mathrm{~A} 5 * 3 \mathrm{U}$, g. $27050 \mathrm{~A}>\mathrm{G})$ of the CY$\mathrm{P} 3 \mathrm{~A} 5$ gene occur in a tight linkage disequilibrium with the CYP3A $5 * 3 \mathrm{C}$ variant. All of these linkages cause functionally defective alleles (Bussi and Createil., 2005; Lakhman et al., 2009). Because CYP3A5 represents at least 50\% of the total hepatic CYP3A content in people polymorphically expressing CYP3A5, it may be the most important genetic contributor to inter-individual and interracial differences in CYP3A-dependent drug clearance and in responses to many medicines (Kuehl et al., 2001). The relevance of CYP3A5 genotyping will depend on the contribution of this enzyme to the total CYP3A-mediated metabolism of a specific drug. For many drugs, this contribution is not exactly known (Huang et al., 2004).

The frequency of the most common $C Y P 3 A 5 * 3$ variant alleles differs among populations and races, ranging from $27-50 \%$ in the African-American population, $60-70 \%$ among Asians, and up to $85-95 \%$ in individuals of Cauca- sian ancestry, in which the expresser variant (CYP3A $5 * 1)$ is uncommon (Park et al., 2008; Coto et al., 2010; Gebeyehu et al., 2011). In addition to the diverse $C Y P 3 A 5 * 3$ frequency across human populations, there are remarkable ethnic-related differences with regard to the frequency of CYP3A5 variants, with an excess of rare variants (Thompson et al., 2004; Sinues et al., 2007; Azarpira et al., 2011). There has been no detailed allele and diplotype analysis of the most common CYP3A5 genetic variant in the Macedonian population.

The objective of this study was therefore to analyze the distribution of the most common CYP3A5 allelic variants in the healthy population of R. Macedonia and to investigate if the allelic frequency falls within the assumed range for European Caucasians.

\section{Materials and methods}

\section{Study population and DNA isolation}

After receiving informed consent, we obtained EDTA whole blood from 194 unrelated healthy donors of a Caucasian origin who self-reported as ethnic Macedonians. Genomic DNA was isolated using Proteinase K digestion, phenol chloroform extraction and ethanol precipita-

Table 1. Genotype distribution of the tested variants in a healthy population of R. Macedonia $(\mathrm{N}=174)^{*}$

\begin{tabular}{|c|c|c|c|c|c|}
\hline CYP3A5 variant & & & $\mathrm{n}^{* *}$ & Observed frequency & $\begin{array}{c}\text { Predicted frequency by } \\
\text { HW eq. }\end{array}$ \\
\hline \multirow{3}{*}{$\begin{array}{c}\text { CYP3A5*3A } \\
(31611 \mathrm{C}>\mathrm{T})\end{array}$} & $\mathrm{CC}$ & $* 1 / * 1$ & 2 & 0.011 & 0.008 \\
\hline & $\mathrm{CT}$ & $* 1 / * 3 \mathrm{~A}$ & 28 & 0.161 & 0.167 \\
\hline & TT & $* 3 \mathrm{~A} / * 3 \mathrm{~A}$ & 144 & 0.828 & 0.825 \\
\hline \multirow{3}{*}{$\begin{array}{l}\text { CYP3A5*3E } \\
(27050 A>G)\end{array}$} & $\mathrm{AA}$ & $* 1 / * 1$ & 132 & 0.759 & 0.758 \\
\hline & $\mathrm{AG}$ & $* 1 / * 3 \mathrm{E}$ & 39 & 0.224 & 0.225 \\
\hline & GG & $* 3 \mathrm{E} / * 3 \mathrm{E}$ & 3 & 0.017 & 0.017 \\
\hline
\end{tabular}

$* \mathrm{~N}$ - total number of subjects in study

** number of subjects

Table 2. Diplotype analysis of CYP3A5*3 allelic variants in Macedonian population.

\begin{tabular}{|c|c|c|c|c|c|c|}
\hline $\begin{array}{c}\text { CYP3A5*3 Diplotype } \\
\text { analysis }\end{array}$ & $31611 \mathrm{C}>\mathrm{T}$ & $27050 A>G$ & $\mathrm{n}$ & Total & $\begin{array}{l}\text { Observed } \\
\text { frequency }\end{array}$ & $\begin{array}{l}\text { Predicted frequency } \\
\text { by HW eq. }\end{array}$ \\
\hline$* 1 / * 1$ & $\mathrm{CC}$ & AA & 2 & 2 & 0.011 & 0.006 \\
\hline \multirow{2}{*}{$* 1 / * 3$} & $\mathrm{CC}$ & $\mathrm{AG}$ & 0 & \multirow{2}{*}{23} & \multirow{2}{*}{0.132} & \multirow{2}{*}{0.143} \\
\hline & $\mathrm{CT}$ & GG & 23 & & & \\
\hline \multirow{4}{*}{$* 3 / * 3$} & $\mathrm{CT}$ & AG & 5 & \multirow{4}{*}{149} & \multirow{4}{*}{0.856} & \multirow{4}{*}{0.851} \\
\hline & TT & AA & 107 & & & \\
\hline & TT & AG & 34 & & & \\
\hline & TT & GG & 3 & & & \\
\hline
\end{tabular}


tion. DNA yields and purity were estimated by measuring the absorbance at $260 \mathrm{~nm}$ and $260 / 280 \mathrm{~nm}$, respectively [NanoDrop 2000, Thermo Scientific] and DNA integrity was confirmed with electrophoresis in $0,8 \%$ agarose gels, stained with ethidium bromide. The Ethical Committee of the Ministry of Health of R. Macedonia approved the study. All personal identifiers were removed and the isolated DNA samples were tested anonymously.

\section{Genotyping procedures}

The designations of all CYP450 alleles refer to those defined by the Cytochrome P450 Allele Nomenclature Committee (http://www.cypalleles.ki.se/). The genotyping of the CYP3A5*3 variant alleles, *3A (rs15524) and *3E (rs28365095), was performed with Real-Time PCR based on the allelic discrimination method [MxPro 3005P, Stratagene, La Jolla, CA, USA] using a TaqMan SNP genotyping assay according to the manufacturer's instructions [Applied Biosystems, Foster City, CA, USA].

\section{Statistical Analysis}

All statistical analyses were performed using the SISA statistical platform. Observed genotype distributions were assessed for the Hardy-Weinberg equilibrium with a $X^{2}$ test. Frequency analyses of an inter-population diversity of the examined polymorphisms were performed on data reported for apparently healthy control populations from several different geographic regions in Europe. The difference in CYP3A5 allelic frequencies between our and other ethnic populations was evaluated using the Chi-squared analysis and Fishers Exact Test. Odds ratios [OR] were calculated with $95 \%$ confidence limits [ $95 \% \mathrm{CI}]$. Factors with $\mathrm{p} \leq 0.05$ were considered statistically significant.

\section{Results}

Genotyping for the CYP3A5*3 allele, CYP3A5*3A (g.31611 C>T) and CYP3A5*3E (g. $27050 \mathrm{~A}>\mathrm{G})$, was successively performed in the total of 174 subjects. The genotype distribution of the CYP3A5*3 variants is summarized in Table 1. Table 2 shows the results of the diplotype analyses. The frequency distributions were consistent with the Hardy-Weinberg equilibrium $(P>0.05)$, indicating that the volunteer pool in this study was likely a representative sample of the population being studied.

Table 3. The CYP3A5*3 allele frequencies in the population of R.Macedonia

\begin{tabular}{ccc}
\hline \hline CYP3A5 polymorphism & Variant allele & $\begin{array}{c}\text { Allele Frequency } \\
(\text { na }=348) *\end{array}$ \\
\hline $31611 \mathrm{C}>\mathrm{T}$ & CYP3A5*3A & 0.908 \\
$27050 \mathrm{~A}>\mathrm{G}$ & CYP3A5*3E & 0.129 \\
$31611 \mathrm{C}>\mathrm{T}+27050 \mathrm{~A}>\mathrm{G}$ & $\mathrm{CYP3A} 5 * 3$ & 0.922 \\
\hline *na - total number of alleles & &
\end{tabular}

The CYP3A5*3A allele was found in 172 subjects with an allelic frequency of 0.908 , while CYP $3 \mathrm{~A} 5 * 3 \mathrm{E}$ was found in 42 subjects with an allelic frequency of 0.129 . Overall, the frequency of the CYP $3 \mathrm{~A} 5 * 3$ diplotype was estimated at 0.922 (Table 3). The CYP3A5*3 variant allele frequency in the healthy population of R. Macedonia com-

Table 4. Allele Frequencies of the CYP3A5*3 variant observed in this study compared with those found in other European ethnic groups

\begin{tabular}{cccccl}
\hline \hline Ethnic group & $\begin{array}{c}\mathrm{N} \\
\text { (study sub- } \\
\text { jects) }\end{array}$ & $\begin{array}{c}\mathrm{n} \\
\text { (total alleles) }\end{array}$ & $\begin{array}{c}\text { CYP3A5*3 allele frequency } \\
* 1\end{array}$ & $* 3$ & \multicolumn{1}{c}{ Reference } \\
\cline { 3 - 5 } R.Macedonia & 174 & 348 & 0.078 & 0.922 & present study \\
Greece & 283 & 566 & 0.057 & 0.943 & Avrantidis et al., 2007 \\
Poland & 200 & 400 & 0.06 & 0.94 & Adler et al., 2009 \\
Belgian & 50 & 100 & 0.06 & 0.94 & Haufroidet al., 2004 \\
Russia & 196 & 392 & 0.06 & 0.94 & Seredina et al.,2012 \\
Germany & 428 & 856 & 0.061 & 0.939 & Dally et al., 2004 \\
Bosnia and Herzegovina & 139 & 278 & 0.068 & 0.932 & Semiz et al., 2011 \\
Italy & 50 & 100 & 0.07 & 0.93 & Turolo et al., 2010 \\
Sweeden & 136 & 272 & 0.07 & 0.93 & Mirghani et al., 2006 \\
Finland & 449 & 898 & 0.079 & 0.921 & Hilli et al., 2007 \\
Netherlands & 500 & 1000 & 0.083 & 0.917 & Van Schauk et al., 2002 \\
Netherlands & 500 & 1000 & 0.07 & 0.914 & Vaarala et al., 2008 \\
Spain & 177 & 354 & 0.09 & 0.91 & Gervasini et al., 2005 \\
Great Britain & 133 & 266 & 0.11 & 0.89 & King et al., 2003 \\
France & 149 & 298 & 0.13 & 0.81 & Quaranta et al., 2006 a \\
\hline
\end{tabular}


pared to data reported from various ethnic groups with European ancestry are presented in Table 4.

\section{Discussion}

Various ethnic groups show different frequencies of CYP450 allelic variants, probably due to ancient migrations of geographically distinct and isolated human groups, combined with the influences of selective factors, such as diet or disease (Lee et al., 2003).

Inter-individual variability in the clearance of CYP3A substrates can result from the effects of inducers, inhibitors, or genetic or dietary factors that potentially lead to differences in drug toxicity and response. According to the published data, CYP3A5 activity varies within any given ethnic population, suggesting that the genetic variation within the CYP3A5 gene may be the most important contributor to inter-individual and interracial differences in CYP3A-dependent drug clearance and response (Makeeva et al., 2008). CYP $3 A 5^{*} 1$ is the only $C Y P 3 A 5$ allele to date that produces high levels of full-length $C Y$ $P 3 A 5$ mRNA and expresses $C Y P 3 A 5$ while the more common $C Y P 3 A 5$ polymorphism in Caucasians, $C Y P 3 A 5^{*} 3$, produces an aberrantly spliced mRNA with a premature stop codon. Marked interethnic differences have been reported for the CYP3A5*3 allelic variant (Roy et al., 2005; Quaranta et al., 2006b).

The present study documents the distribution of CYP3A $5 * 3$ in a population of $\mathrm{R}$. Macedonia. The $C Y P 3 A 5^{*} 3$ allele was abundantly present in the subjects of our study, with an allelic frequency of 0.922 . We observed no statistically significant difference $(\mathrm{p}>0.05)$ compared to CYP3A5*3 frequency data reported for other European ethnic groups. The frequency of the CYP3A $5 * 3$ variant allele in our population was interpolated between 0.94 in Greece, Poland, Belgium, Russia and Germany; 0.93 in Bosnian and Herzegovina, Italy and Sweden; 0.92 in Finland, 0.91 in Netherlands, Spain and Croatia; 0.89 in Great Britain and 0.81 in France. This is in good concordance with the described trend of the increasing gradient of $C Y P 3 A 5^{*} 1$ allele frequency from north to south of the globe (Suarez-Kurtz et al., 2007).

The CYP3A5*3 homozygotes lack CYP3A5 expression (non expressors) and are associated with a phenotype of decreased metabolic capacity. Conversely, in individuals with at least one $C Y P 3 A 5^{*} 1$ wild type allele, CYP3A5 accounts for at least $50 \%$ of the total CYP3A content, and results in a 2- to 3-fold higher total CYP3A catalityc activity (Zeigler-Johnson et al., 2004; Press et al., 2009) . This expression variability might be an explanation for the differences in dose requirements in patients who are treated with drugs that are cleared by CYP3A5; CYP $3 A 5^{*} 3$ homozygotes would require a lower dose of the drug to reach the blood concentration target, compared to CYP $3 A 5 * 1$ homozygotes (Solas et al., 2007; Roco et al., 2012). However, although several studies have attempted to correlate the metabolic capabilities of different patients with the genotype, a clear relationship between the levels of CYP3A5 expression and/or activity and genetic markers remains to be established (Wang et al., 2012).

In the studied population of 174 subjects, $0.011(\mathrm{n}=$ 2) were homozygous for the $* 1$ allele, $0.856(\mathrm{n}=149)$ for the $* 3$ allele, and $0.132(\mathrm{n}=23)$ were $* 1 / * 3$ heterozygotes. Since heterozygotes for $C Y P 3 A 5 * 3$ may have some CYP3A5 activity, we estimate that 0.86 of the Macedonian population do not have a CYP3A5 enzymatic activity. This is in agreement with the finding that $10 \%$ of the Caucasians were high expressers of CYP3A5 (Van Schaik et al., 2002).

Several lines of evidence suggest that the distribution of CYP3A5 genetic variants in people living in the developing countries may differ from that of people living in industrialized countries due to the selection pressure exerted on specific alleles by different environmental factors present in these geographic areas. To date, most studies on the Cyp3A5 polymorphism have been conducted in populations from industrialized countries (Roy et al., 2005).

Since no data were available for the Macedonian ethnic group, we would like to emphasize the value of these results, which may serve as a background for comparison with other population samples and could be included in case-control studies as a reference.

\section{Conclusion}

Our study demonstrated the high prevalence of CYP3A5*3 allele in the Macedonian population. The distribution of $C Y P 3 A 5$ alleles was similar to that found in other European Caucasians. As the goals of personalized medicine are beginning to be realized, this provides basic information on the CYP3A5 allele frequency for the future pharmacogenetic research in R. Macedonia.

\section{References}

Adler, G., Łoniewska, B., Parczewski, M., Kordek,A., Ciechanowicz, A., 2009. Frequency of common CYP3A5 gene variants in healthy Polish newborn infants. Pharmacol Rep 61, 947-951.

Arvanitidis, K., Ragia, G., Iordanidou, M., Kyriaki, S., Xanthi, A., Tavridou, A., Manolopoulos, V.G., 2007. Genetic polymorphisms of drug-metabolizing enzymes CYP2D6, CYP2C9, CYP2C19 and CYP3A5 in the Greek population. Fundam Clin Pharmacol 21, 419-426.

Azarpira, N., Namazi, S., Khalili, A., Tabesh, M., 2011. The investigation of allele and genotype frequencies of CYP3A5 (1/3) and P2Y12 (T744C) in Iran. Mol. Biol. Rep. 38, 4873-4877.

Busi, F., Cresteil, T., 2005. CYP3A5 mRNA degradation by nonsensemediated mRNA decay. Mol. Pharmacol. 68, 808-815.

Coto, E., Tavira, B., Marín, R., Ortega, F., López-Larrea, C., Ruiz-Ortega, M., Ortiz, A., Díaz, M., Corao, A.I., Alonso, B., Alvarez, V., 2010. Functional polymorphisms in the CYP3A4, CYP3A5, and CYP21A2 genes in the risk for hypertension in pregnancy. Biochem. Biophys. Res. Commun. 397, 576-579. 
Dally, H., Bartsch, H., Jäger, B., Edler, L., Schmezer, P., Spiegelhalder, B., Dienemann, H., Drings, P., Kayser, K., Schulz, V., Risch, A., 2004. Genotype relationships in the CYP3A locus in Caucasians. Cancer Lett. 207, 95-99.

Garsa, A.A., McLeod, H.L., Marsh, S., 2005. CYP3A4 and CYP3A5 genotyping by Pyrosequencing. BMC Med. Genet. 6, 19.

Gebeyehu, E., Engidawork, E., Bijnsdorp, A., Aminy, A., Diczfalusy, U., Aklillu, E., 2011. Sex and CYP3A5 genotype influence total CYP3A activity: high CYP3A activity and a unique distribution of CYP3A5 variant alleles in Ethiopians. Pharmacogenomics J. 11, 130-137.

Gervasini, G., Vizcaino, S., Gasiba, C., Carrillo, J.A., Benitez, J., 2005. Differences in CYP3A5*3 genotype distribution and combinations with other polymorphisms between Spaniards and Other Caucasian populations. Ther Drug Monit 27, 819-821.

Haufroid, V., Mourad, M., Van Kerckhove, V., Wawrzyniak, J., De Meyer, M., Eddour, D.C., Malaise, J., Lison, D., Squifflet, J.-P., Wallemacq, P., 2004. The effect of CYP3A5 and MDR1 (ABCB1) polymorphisms on cyclosporine and tacrolimus dose requirements and trough blood levels in stable renal transplant patients. Pharmacogenetics 14, 147-154.

He, P., Court, M.H., Greenblatt, D.J., von Moltke, L.L., 2006. Factors influencing midazolam hydroxylation activity in human liver microsomes. Drug Metab. Dispos. 34, 1198-1207.

Hilli, J., Rane, A., Lundgren, S., Bertilsson, L., Laine, K., 2007. Genetic polymorphism of cytochrome P450s and P-glycoprotein in the Finnish population. Fundam Clin Pharmacol 21, 379-386.

Huang, W., Lin, Y.S., McConn, D.J., 2nd, Calamia, J.C., Totah, R.A., Isoherranen, N., Glodowski, M., Thummel, K.E., 2004. Evidence of significant contribution from CYP3A5 to hepatic drug metabolism. Drug Metab. Dispos. 32, 1434-1445.

King, B.P., Leathart, J.B.S., Mutch, E., Williams, F.M., Daly, A.K., 2003. CYP3A5 phenotype-genotype correlations in a British population. Br J Clin Pharmacol 55, 625-629.

Kuehl, P., Zhang, J., Lin, Y., Lamba, J., Assem, M., Schuetz, J., Watkins, P.B., Daly, A., Wrighton, S.A., Hall, S.D., Maurel, P., Relling, M., Brimer, C., Yasuda, K., Venkataramanan, R., Strom, S., Thummel, K., Boguski, M.S., Schuetz, E., 2001. Sequence diversity in CYP3A promoters and characterization of the genetic basis of polymorphic CYP3A5 expression. Nat. Genet. 27, 383-391.

Lakhman, S.S., Ma, Q., Morse, G.D., 2009. Pharmacogenomics of CYP3A: considerations for HIV treatment. Pharmacogenomics 10, 1323-1339.

Lee, S.-J., Usmani, K.A., Chanas, B., Ghanayem, B., Xi, T., Hodgson, E., Mohrenweiser, H.W., Goldstein, J.A., 2003. Genetic findings and functional studies of human CYP3A5 single nucleotide polymorphisms in different ethnic groups. Pharmacogenetics 13, 461-472.

Makeeva, O., Stepanov, V., Puzyrev, V., Goldstein, D.B., Grossman, I., 2008. Global pharmacogenetics: genetic substructure of Eurasian populations and its effect on variants of drug-metabolizing enzymes. Pharmacogenomics 9, 847-868.

Mirghani, R.A., Sayi, J., Aklillu, E., Allqvist, A., Jande, M., Wennerholm, A., Eriksen, J., Herben, V.M.M., Jones, B.C., Gustafsson, L.L., Bertilsson, L., 2006. CYP3A5 genotype has significant effect on quinine 3-hydroxylation in Tanzanians, who have lower total CYP3A activity than a Swedish population. Pharmacogenet. Genomics 16, 637-645.

Paine, M.F., Hart, H.L., Ludington, S.S., Haining, R.L., Rettie, A.E., Zeldin, D.C., 2006. The human intestinal cytochrome
P450 “pie”. Drug Metab. Dispos. 34, 880-886.

Park, S.Y., Kang, Y.S., Jeong, M.S., Yoon, H.K., Han, K.O., 2008. Frequencies of CYP3A5 genotypes and haplotypes in a Korean population. J Clin Pharm Ther 33, 61-65.

Press, R.R., Ploeger, B.A., den Hartigh, J., van der Straaten, T., van Pelt, J., Danhof, M., de Fijter, J.W., Guchelaar, H.-J., 2009. Explaining variability in tacrolimus pharmacokinetics to optimize early exposure in adult kidney transplant recipients. Ther Drug Monit 31, 187-197.

Quaranta, S., Chevalier, D., Bourgarel-Rey, V., Allorge, D., Solas, C., Lo-Guidice, J.-M., Sampol-Manos, E., Vacher-Coponat, H., Moal, V., Broly, F., Lhermitte, M., Lacarelle, B., 2006a. Identification by single-strand conformational polymorphism analysis of known and new mutations of the CYP3A5 gene in a French population. Toxicol. Lett. 164, 177-184.

Quaranta, S., Chevalier, D., Allorge, D., Lo-Guidice, J.M., MigotNabias, F., Kenani, A., Imbenotte, M., Broly, F., Lacarelle, B., Lhermitte, M., 2006b. Ethnic differences in the distribution of CYP3A5 gene polymorphisms. Xenobiotica 36, 1191-1200.

Roco, A., Quiñones, L., Agúndez, J.A.G., García-Martín, E., Squicciarini, V., Miranda, C., Garay, J., Farfán, N., Saavedra, I., Cáceres, D., Ibarra, C., Varela, N., 2012. Frequencies of 23 functionally significant variant alleles related with metabolism of antineoplastic drugs in the chilean population: comparison with caucasian and asian populations. Front Genet 3, 229.

Roy, J.-N., Lajoie, J., Zijenah, L.S., Barama, A., Poirier, C., Ward, B.J., Roger, M., 2005. CYP3A5 genetic polymorphisms in different ethnic populations. Drug Metab. Dispos. 33, 884-887.

Semiz, S., Dujić, T., Ostanek, B., Prnjavorac, B., Bego, T., Malenica, M., Mlinar, B., Marc, J., Causević, A., 2011. Analysis of CYP3A4*1B and CYP3A $5 * 3$ polymorphisms in population of Bosnia and Herzegovina. Med Glas (Zenica) 8, 84-89.

Seredina, T.A., Goreva, O.B., Talaban, V.O., Grishanova, A.Y., Lyakhovich, V.V., 2012. Association of cytochrome P450 genetic polymorphisms with neoadjuvant chemotherapy efficacy in breast cancer patients. BMC Med. Genet. 13, 45.

Sinues, B., Vicente, J., Fanlo, A., Vasquez, P., Medina, J.C., Mayayo, E., Conde, B., Arenaz, I., Martinez-Jarreta, B., 2007. CYP3A5*3 and CYP3A4*1B allele distribution and genotype combinations: differences between Spaniards and Central Americans. Ther Drug Monit 29, 412-416.

Solas, C., Simon, N., Drogoul, M.-P., Quaranta, S., FrixonMarin, V., Bourgarel-Rey, V., Brunet, C., Gastaut, J.-A., Durand, A., Lacarelle, B., Poizot-Martin, I., 2007. Minimal effect of MDR1 and CYP3A5 genetic polymorphisms on the pharmacokinetics of indinavir in HIV-infected patients. Br J Clin Pharmacol 64, 353-362.

Suarez-Kurtz, G., Perini, J.A., Bastos-Rodrigues, L., Pena, S.D.J., Struchiner, C., 2007. Impact of population admixture on the distribution of the CYP3A $5 * 3$ polymorphism. Pharmacogenomics 8, 1299-1306.

Thompson, E.E., Kuttab-Boulos, H., Witonsky, D., Yang, L., Roe, B.A., Di Rienzo, A., 2004. CYP3A variation and the evolution of salt-sensitivity variants. Am. J. Hum. Genet. 75, 1059-1069.

Turolo, S., Tirelli, A.S., Ferraresso, M., Ghio, L., Belingheri, M., Groppali, E., Torresani, E., Edefonti, A., 2010. Frequencies and roles of CYP3A5, CYP3A4 and ABCB1 single nucleotide polymorphisms in Italian teenagers after kidney transplantation. Pharmacol Rep 62, 1159-1169.

Vaarala, M.H., Mattila, H., Ohtonen, P., Tammela, T.L.J., Paavonen, T.K., Schleutker, J., 2008. The interaction of 
CYP3A5 polymorphisms along the androgen metabolism pathway in prostate cancer. Int. J. Cancer 122, 2511-2516.

Van Schaik, R.H.N., van der Heiden, I.P., van den Anker, J.N., Lindemans, J., 2002. CYP3A5 variant allele frequencies in Dutch Caucasians. Clin. Chem. 48, 1668-1671.

Wang ,D., Sadee,W., 2012. The Making of a CYP3A Biomarker
Panel for Guiding Drug Therapy. J. Pers. Med. 2, 175-191. Zeigler-Johnson, C., Friebel, T., Walker, A.H., Wang, Y., Spangler, E., Panossian, S., Patacsil, M., Aplenc, R., Wein, A.J., Malkowicz, S.B., Rebbeck, T.R., 2004. CYP3A4, CYP3A5, and CYP3A43 genotypes and haplotypes in the etiology and severity of prostate cancer. Cancer Res. $64,8461-8467$.

\title{
Резиме
}

\section{Фрекфенција на најчестите CYP3А5 полиморфизми во здрава популација во Република Македонија}

\author{
Круме Јаковски ${ }^{1}$,Александра Капедановска Несторовска², Никола Лабачевски ${ }^{1}$, \\ Александар J. Димовски ${ }^{2}$
}

\author{
${ }^{1}$ Институт за Предклиничка и Клиничка Фрамакологија и Токсикологија, Медицински Факултет, \\ Универзитет „,Св.Кирил и Методиј“ - Скопје, Р.Македонија. \\ ${ }^{2}$ Центар за Биомолекуларни Фармацевтски Анализи, Фармацевтски факултет, \\ Универзитет „Св.Кирил и Методиј“ - Скопје, Р.Македонија.
}

Клучни зборови: еднонуклеотидни полиморфизми, СYР3А5, популациона фрекфенција, Република Македонија

Утврдено е дека генетските полиморфизми кои влијаат на активноста на СҮР3А5 ензимот претставуваат еден од факторите кои придонесуваат за интериндивидуална и интеретничка варијабилност во метаболизмот на СҮР3А5 субстратите. Целта на ова истражување беше да се одреди дистрибуцијата на најчестите CYP3A $5 * 3$ полиморфни варијанти во здрава популација од Република Македонија и да се утврди дали фреквенцијата на варијантните алели е во рамките на публикуваните податоци за Европската популација. Во студијата беа вклучени вкупно 174 здрави доброволци од генералната популација од Р. Македонија. Генотипизацијата на СРР3А5*3 варијантните алели, *3А (rs15524) и *3E (rs28365095), беше направена со примена на методот на Real-Time Полимераза Верижна Реакција (Polymerase Chain Reaction- PCR) [MxPro 3005P, Stratagene, La Jolla, CA, USA] и употреба на специфични TaqMan SNP тестови за генотипизација, во услови согласно препораките на производителот [Applied Biosystems, Foster City, CA, USA]. Добиените резултати покажуваат дека CYP3A5*3 алел е доминантно присутен во фрекфенција од 0.922. Приближно $82 \%$ од Македонската популација се хомозиготи за варијантниот алел и воопшто не поседуваат СҮР 3 А5 ензимска активност. Дистрибуцијата на испитуваните СҮР 35 полиморфизми во Р. Македонија е слична со дистрибуцијата на другите Европски популации. Овие резултати претставуваат основа за понатамошни фармакогенетски истражувања во нашата држава. 